\title{
CORRELATION OF DIFFERENT ANTHROPOMETRIC METHODS AND BIOELECTRIC IMPEDANCE IN ASSESSING BODY FAT PERCENTAGE OF PROFESSIONAL MALE ATHLETES
}

\author{
Marko Dimitrijevic ${ }^{1}$, Dijana Lalovic ${ }^{2}$ and Djordje Milovanov ${ }^{3}$ \\ ${ }^{I}$ Department of Physiology, Faculty of Medical Sciences, University of Kragujevac, Kragujevac, Serbia \\ ${ }^{2}$ Medical High School "Nadezda Perovic”, Zemun, Belgrade, Serbia \\ ${ }^{3}$ Faculty of Sport and Physical Education, University of Novi Sad,Novi Sad, Serbia
}

\author{
KORELACIJA RAZLIČITIH ANTROPOMETRIJSKIH METODA I \\ BIOELEKTRIČNE IMPEDANCE U PROCENI PROCENTA TELESNIH \\ MASTI KOD PROFESIONALNIH MUŠKIIH SPORTISTA \\ Marko Dimitrijević ${ }^{1}$, Dijana Lalović², Đorđe Milovanov ${ }^{3}$ \\ ${ }^{l}$ Katedra za fiziologiju, Fakultet medicinskih nauka, Univerzitet u Kragujevcu, Kragujevac, Srbija \\ ${ }^{2}$ Visoka medicinska škola "Nadezda Perovic”, Zemun, Beograd, Srbija \\ ${ }^{3}$ Fakultet sporta i fizičkog vaspitanja, Univerzitet u Novom Sadu, Novi Sad, Srbija
}

\begin{abstract}
Introduction: Studies examining correlation of existing anthropometric methods developed for specific and general athlete population and BIA method are much more scarce and often conducted using only one anthropometry method for comparison with BIA method per study. Aim: Examination of the correlation between different anthropometric methods and BIA method in assessing body fat percentage of general male athlete population. Method: The study was conducted using 85 professional athletes from Serbia, average age of 23,7 \pm 4,3 years. Correlation between anthropometric methods and BIA method was examined using Spearman rang correlation. Sixteen anthropometric equations using a total of ten skinfolds were selected from eleven anthropometric methods developed for specific or general male athlete population. Results: All sixteen anthropometric equations revealed a strong correlation with BIA method. Faulkner's anthropometric skinfold equation $(\% B F=5,783+(0,153$ (triceps + subscapular + supra-iliac + abdominal)) revealed the strongest correlation coefficient $\left(r_{s}=0,792\right)$ and the shortest bias-corrected and accelerated confidence interval length (BCa CI 95\% (0,712 0,849)). Conclusion: Even though ten of the sixteen anthropometric equations revealed a very strong correlation, Faulkner's equation showed the largest Spearman's correlation coefficient with BIA method in assessing body fat of professional male athletes. Faulkner's equation may be the best candidate that can be used as replacement of BIA method for general male athlete population. It would be useful and interesting to repeat a similar study with the addition of one of the referent methods from the second level of validity group.
\end{abstract}

Keywords: body fat, anthropometry, skinfolds, anthropometric equation, male athletes, bioelectrical impedance, BIA.

\section{SAŽETAK}

Uvod: Studije koje ispituju postojeće antropometrijske metode konstruisane za specifičnu i opštu populaciju sportista i BIA metode su daleko oskudnije i često sprovedene koristeći u studiji samo jednu antropometrijsku metodu za utvrdivanje korelacije sa BIA metodom. Cilj: Ispitivanje korelacije različitih antropometrijskih metoda i BIA metode u proceni procenta telesnih masti kod opšte muške populacije sportista. Metod: Studija je sprovedena na uzorku od 85 profesionalnih sportista iz Srbije, prosečne starosti 23,7 \pm 4,3 godina. Za ispitivanje korelacije antropometrijskih metoda i BIA metode je uporebljena Spirmanova rang korelacija. Šesnaest antropometrijskih jednačina kod kojih je upotrebljeno ukupno deset različitih kožnih nabora je odabrano iz jedanaest antropometrijskih metoda. Rezultati: Svih šesnaest antropometrijskih jednačina su ukazivale na jaku korelaciju sa BIA metodom. Folknerova jednačina je pokazala najjaču korelaciju $(\% B F$ $=5,783+(0,153$ (triceps + subskapularni + supra-ilijačni $+a b-$ dominalni)) i najuži interval pouzdanosti (BCa CI 95\% (0,712 - 0,849)). Zaključak: Iako je svih šesnaest antropometrijskih jednačina pokazalo jaku korelaciju, Folknerova antropometrijska jednačina je jedina pokazala Spirmanov koeficijent korelacije na granici između jake $i$ vrlo jake korelacije sa BIA metodom u proceni procenta telesnih masti kod opšte muške populacije sportista. Folknerova jednačina može biti najbolji kandidat koji bi mogao da se upotrebi kao zamena za BIA metodu kod opšte muške populacije sportista. Bilo bi korisno i interesantno ponoviti sličnu studiju sa dodatkom jedne od referentnih metoda iz grupe drugog nivoa validnosti.

Ključne reči: telesna masnoća, antropometrija, kožni nabori, antropometrijska jednačina, muški sportisti, bioelektrična impedansa, BIA. 


\section{INTRODUCTION}

Body composition component in form of fat tissue is very important for sports performance $(1,2,3,4,5,6,7)$ It is known that body fat percentage affects the cardiorespiratory ability of male athletes (8), as well that both high and low levels of body fat can put athletes in an unwanted situation (9). Today we are familiar with a large number of methods that can be applied in the analysis of body composition. More precise methods for body composition analysis such as magnetic resonance imaging (MRI), computed tomography (CT), dualenergy X-ray absorptiometry (DXA), plethysmography (ADP) and other second level validity methods are rarely available to us due to financial constraints and the need for trained staff. Because of this, alternative, third level validity methods such as anthropometry and bioelectrical impedance analysis are far more often used on a daily basis for general population, i.e. for non-athletes, people who do recreational sports and athletes. Besides a far more affordable price, the advantages of these alternative methods are also reflected in non-invasiveness, portability and in their simple and fast application in body composition analysis.

On the other hand, one of the biggest disadvantages of these methods is that they are considered less accurate than the aforementioned second level validity methods. In practice we can find numerous anthropometric methods, but the most common ones are those using measured values of skinfolds thickness at defined points of the body and specific mathematical formulas to estimate the body fat percentage. The most common bioelectrical impedances (BIA) are portable models, which today can be seen more and more often in fitness and wellness centers, but also in private homes. Both BIA and anthropometric methods are considered to have a measurement error in estimating body fat of about $\pm 3.5 \%$, assuming that all preconditions for measurement and analysis are fulfilled (10). However, in situations where athletes have to travel, anthropometric methods still show certain portable advantages. Anthropometric equipment is more practical for transporting compared to BIA analyzers being bigger in size, robust and carry the risk of electronic component damage or failure. Bioelectrical impedance also requires an athlete preparation protocol starting 48 hours prior to measurement which is not practical when going on a trip, while with anthropometry this is not the case. There is also the possibility of temporal disruption of physiological systems caused by air travel or any longer land travel that may lead to somewhat reduced accuracy of BIA, which is not the case with anthropometry where the measurement is performed anatomically. This can influence coaches, sports experts or sports physicians to use anthropometry, especially in situations where athletes often change location and travel to away games, competitions and preparation camps. When it comes to male athletes, Forsythe and Sinning already investigated back in 1973. and pointed out that anthropometric equations developed for the general non-athletic population are not accurate enough in estimating body fat in male athletic population. (11). Throughout decades, numerous anthropometric methods based on sport specificity have been developed through research $(12,13,14)$ and also based on general samples of athletes from different sports, by determining the correlation of these methods with one of the second level validity reference methods $(11,15,16,17,18,19)$ in evaluating body fat of athletes. A smaller number of studies have been conducted in examining the correlation between anthropometric methods and BIA method in general population of male athletes or in sport-specific male population, where second level validity reference method was not included $(20,21)$. However, these studies often examined the correlation of anthropometric methods and BIA method by using only one sports anthropometric method and equation in the study. Determining whether some of the already existing and represented sports anthropometric methods (sports-specific or general sports methods) can replace BIA method in estimating body fat percentage of general male athlete population could be one of the solutions for athletes, coaches and sports experts to avoid confusion and encourage them to use anthropometry in the field of practice, either for traveling needs or using it as personal preference.

In accordance with the previous, the aim of this study is to examine the correlation of different anthropometric methods and BIA methods in estimating body fat percentage of male professional athletes from different sports.

\section{MATERIALS AND METHODS}

\section{Participants}

The study included eighty five professional athletes $(\mathrm{N}=85), 17-33$ years of age, recruited from four different sports, wrestling $(n=28)$, football $(n=28)$, boxing $(n=15)$ and basketball $(n=14)$. All recruited athletes were members of FIT IN health-related fitness club in Belgrade, where they performed part of their conditioning procedures. The inclusion criteria included athletes who were competing in sports for more than 3 years and not having any long training breaks or any rest caused by an injury or any other factor within last six months.

\section{Procedures}

Athletes were examined in the laboratory for sports medicine and exercise therapy at the Institute of Physiology "Richard Burian" in Belgrade. Anthropometric measurement procedures was conducted in accordance with the guidelines and recommendations of International Standards for Anthropometric Assessment (ISAK) (22,23). Procedure for BIA analysis was conducted using BIA pre-test guidelines (24). Athletes were not pressured to participate in the study and after being well informed they voluntarily signed the consent form for participating in the study. 
Table 1. Athlete characteristics

\begin{tabular}{|c|c|c|c|c|c|}
\hline Sport & $\begin{array}{l}\text { Basketball } \\
(n=14)\end{array}$ & $\begin{array}{c}\text { Football } \\
(\mathbf{n}=\mathbf{2 8})\end{array}$ & $\begin{array}{r}\text { Boxing } \\
(n=15)\end{array}$ & $\begin{array}{c}\text { Wrestling } \\
(\mathbf{n}=\mathbf{2 8})\end{array}$ & $\begin{array}{c}\text { Total } \\
(\mathbf{N}=\mathbf{8 5})\end{array}$ \\
\hline Variables & $\begin{array}{l}\mathrm{X} \pm \mathrm{SD} \\
\text { range }\end{array}$ & $\begin{array}{l}\mathrm{X} \pm \mathrm{SD} \\
\text { range }\end{array}$ & $\begin{array}{l}\mathrm{X} \pm \mathrm{SD} \\
\text { range }\end{array}$ & $\begin{array}{l}\mathrm{X} \pm \mathrm{SD} \\
\text { range }\end{array}$ & $\begin{array}{l}\mathrm{X} \pm \mathrm{SD} \\
\text { range }\end{array}$ \\
\hline $\begin{array}{c}\text { Age } \\
\text { (years) }\end{array}$ & $\begin{array}{c}25,4 \pm 4,2 \\
17,2-31\end{array}$ & $\begin{array}{c}23,9 \pm 4,2 \\
17,5-33\end{array}$ & $\begin{array}{c}23,687 \pm 4,2 \\
17,4-32,2\end{array}$ & $\begin{array}{l}21,4 \pm 6,4 \\
17,5-32,9\end{array}$ & $\begin{array}{c}23,7 \pm 4,3 \\
17,2-33\end{array}$ \\
\hline $\begin{array}{l}\text { Height } \\
\text { (cm) }\end{array}$ & $\begin{array}{c}198,3 \pm 10,8 \\
171,2-211\end{array}$ & $\begin{array}{c}181,9 \pm 5,1 \\
169,0-190,5\end{array}$ & $\begin{array}{c}186,4 \pm 7,2 \\
175-198\end{array}$ & $\begin{array}{c}176,7 \pm 7,7 \\
155,0-191,5\end{array}$ & $\begin{array}{c}183,7 \pm 10,4 \\
155-211\end{array}$ \\
\hline $\begin{array}{l}\text { Weight } \\
\text { (kg) }\end{array}$ & $\begin{array}{l}96,1 \pm 19,2 \\
43,7-120,6\end{array}$ & $\begin{array}{l}77,2 \pm 5,6 \\
67,3-86,5\end{array}$ & $\begin{array}{l}87,7 \pm 17,5 \\
59,8-123,4\end{array}$ & $\begin{array}{l}80,6 \pm 11,7 \\
59,5-105,2\end{array}$ & $\begin{array}{l}83,3 \pm 14,4 \\
43,7-123,4\end{array}$ \\
\hline$\underset{\left(\mathrm{kg} / \mathrm{m}^{2}\right)}{\mathrm{BMI}}$ & $\begin{array}{c}24,1 \pm 3 \\
14,9-27,3\end{array}$ & $\begin{array}{l}23,3 \pm 1,1 \\
21,2-25,3\end{array}$ & $\begin{array}{l}25,1 \pm 3,4 \\
19,3-32,3\end{array}$ & $\begin{array}{l}25,7 \pm 2,5 \\
22,4-31,2\end{array}$ & $\begin{array}{l}24,6 \pm 2,6 \\
14,9-32,3\end{array}$ \\
\hline$\underset{\left(\mathrm{kg} / \mathrm{m}^{2}\right)}{\text { FFMI }}$ & $\begin{array}{c}21,7 \pm 2,5 \\
14-25,4\end{array}$ & $\begin{array}{l}21,2 \pm 0,9 \\
19,7-22,9\end{array}$ & $\begin{array}{l}21,9 \pm 2,2 \\
17,6-26,4\end{array}$ & $\begin{array}{l}22,4 \pm 1,7 \\
20,1-26,1\end{array}$ & $\begin{array}{c}21,8 \pm 1,8 \\
14-26,4\end{array}$ \\
\hline $\begin{array}{l}\text { BIA-BF } \\
\text { (\%) }\end{array}$ & $\begin{array}{c}10 \pm 3,2 \\
5,5-15,4\end{array}$ & $\begin{aligned} 8,8 & \pm 2,1 \\
169,0 & -190,5\end{aligned}$ & $\begin{array}{c}12,2 \pm 3,6 \\
7-19,2\end{array}$ & $\begin{array}{l}12,6 \pm 2,8 \\
7,4-18,4\end{array}$ & $\begin{array}{l}10,8 \pm 3,3 \\
4,9-19,2\end{array}$ \\
\hline
\end{tabular}

$\mathrm{X}$ - mean; SD - standard deviation; $\mathrm{n}$ - number of subjects within a group; $\mathrm{N}$ - total number of subjects; $\mathrm{BMI}$ - body mass index; FFMI - fat-free mass index; BIA-BF - body fat percentage estimated with bioelectrical impedance.

\section{Equipment}

Skinfolds measurement was performed using Harpenden caliper (model HSB-BI, produced by company HaB Direct, United Kingdom) with measuring range from 0 to $80 \mathrm{~mm}$ (caliper needle can go four full circles around a dial scale with gradation from 0 to $20 \mathrm{~mm}$ ), measuring pressure on a lifted skinfold of $10 \mathrm{gr} / \mathrm{mm}^{2}$ and reading accuracy of $0.2 \mathrm{~mm}$. Athletes height was measured with roll-up measuring tape with wall attachment (model SECA 206, produced by SECA, Germany), providing measuring range of $0-220 \mathrm{~cm}$ with 1 $\mathrm{mm}$ gradation. Body weight measurement and estimation of body fat were conducted using hand-to-foot type BIA (model InBody 230, produced by InBody, Republic of Korea). All additional needed equipment was prepared and calibrated before measurement took place.

\section{Anthropometric and BIA measurement}

Anthropometric measurement of skinfolds was conducted using ISAK guidelines and recommendations $(22,23)$. Bioelectrical impedance analysis was conducted according to the manufacturer's instructions for model InBody 230. Complete testing of every individual athlete was conducted on the same day. Upon testing arrival, athletes performed BIA analysis first, having their body fat percentage assessed and their body weight measured. After BIA analysis was completed anthropometric measurements of body height and skinfolds thickness were conducted. An anthropometrist with a decade of experience in practice was recruited for anthropometric measurement.

\section{Anthropometric methods}

Eleven anthropometric methods designed for different male athlete populations were selected for the study and then a total of sixteen skinfold equations (formulas) were selected from these methods (Table 2). The inclusion criterion for anthropometric equations was met with equations being developed for a specific sport population or for general male sport population, by using only measurements of skinfolds or measurements of skinfolds combined with some of the basic anthropometric or descriptive characteristics such as body height and weight, body mass index and age. Also, only equations developed through regression analysis with the highest multiple correlation coefficients between a dependent variable and a group of independent variables $(\mathrm{R})$ or that explained the largest variance in dependent variable by using independent variables $\left(\mathrm{R}^{2}\right)$ (depending on what was reported in an individual study, $\mathrm{R}$ or $\mathrm{R}^{2}$ ), when these anthropometric equations were correlated with referent methods within a study. 
Table 2. Selected anthropometric methods and equations developed for assessing body fat in different male athlete populations.

\begin{tabular}{|c|c|}
\hline $\begin{array}{l}\text { Author(s)/ } \\
\text { method }\end{array}$ & Anthropometric equation \\
\hline $\begin{array}{l}\text { Yuhasz } \\
(25)\end{array}$ & $\begin{array}{c}\text { Equation using } 6 \text { skinfolds. } \\
\% \mathrm{BF}=3,64+(0,097(\mathrm{Ch}+\mathrm{Tr}+\mathrm{Sb}+\mathrm{Si}+\mathrm{Ab}+\mathrm{Th}))\end{array}$ \\
\hline $\begin{array}{l}\text { Faulkner } \\
\quad(26)\end{array}$ & $\begin{array}{l}\text { Equation using } 4 \text { skinfolds, today considered a modified Yuhasz method } \\
\qquad \% \mathrm{(27)} \text {. } \\
\qquad \% \mathrm{BF}=5,783+(0,153(\mathrm{Tr}+\mathrm{Sb}+\mathrm{Si}+\mathrm{Ab}))\end{array}$ \\
\hline $\begin{array}{l}\text { Forsyth \& } \\
\text { Sinning } 1 \\
(11)\end{array}$ & $\begin{array}{l}\text { Equation using } 2 \text { skinfolds (equation no. } 2 \mathrm{a}) \text {. } \\
\mathrm{BD}=1,103-(0,00168 \times \mathrm{Sb})-(0,00127 \times \mathrm{Ab})\end{array}$ \\
\hline $\begin{array}{l}\text { Forsyth \& Sin- } \\
\text { ning } 2 \\
(11)\end{array}$ & $\begin{array}{c}\text { Equation using } 4 \text { skinfolds (equation no. } 2 \mathrm{~b}) \\
\mathrm{BD}=1,10647-(0,00162 \times \mathrm{Sb})-(0,00144 \times \mathrm{Ab})-(0,00077 \times \mathrm{Tr})+ \\
(0,00071 \times \mathrm{Ma})\end{array}$ \\
\hline $\begin{array}{l}\text { Forsyth \& Sin- } \\
\text { ning } 3 \\
(11)\end{array}$ & $\begin{array}{c}\text { Equation using } 2 \text { skinfolds and height (equation no. 3a). } \\
\mathrm{BD}=1,02415-(0,00169 \times \mathrm{Sb})+(0,00444 \times \mathrm{Ht})-(0,00130 \times \mathrm{Ab})\end{array}$ \\
\hline $\begin{array}{l}\text { Forsyth \& Sin- } \\
\text { ning } 4 \\
(11)\end{array}$ & $\begin{array}{c}\text { Equation using } 4 \text { skinfolds and height (equation no. 3b }) . \\
\mathrm{BD}=1,03316-(0,00164 \times \mathrm{Sb})+(0,00410 \times \mathrm{Ht})-(0,00144 \times \mathrm{Ab})- \\
(0,00069 \times \mathrm{Tr})+(0,00062 \times \mathrm{Ma})\end{array}$ \\
\hline $\begin{array}{l}\text { White et al. } \\
\text { (12) }\end{array}$ & $\begin{array}{c}\text { Equation using } 2 \text { skinfolds. } \\
\mathrm{BD}=1,0958-(0,00088 \times \mathrm{Si})-(0,0006 \times \mathrm{Th})\end{array}$ \\
\hline $\begin{array}{l}\text { Thorland et al. } 1 \\
\qquad(19)\end{array}$ & $\begin{array}{c}\text { Equation using } 7 \text { skinfolds. } \\
\mathrm{BD}=1,1091-(0,00052(\mathrm{Tr}+\mathrm{Sb}+\mathrm{Ma}+\mathrm{Si}+\mathrm{Ab}+\mathrm{Th}+\mathrm{Ca}))+ \\
\left(0,00000032(\mathrm{Tr}+\mathrm{Sb}+\mathrm{Ma}+\mathrm{Si}+\mathrm{Ab}+\mathrm{Th}+\mathrm{Ca})^{2}\right)\end{array}$ \\
\hline $\begin{array}{l}\text { Thorland et al. } 2 \\
\qquad(19)\end{array}$ & $\begin{array}{c}\text { Equation using } 3 \text { skinfolds. } \\
\mathrm{BD}=1,1136-(0,00154(\mathrm{Tr}+\mathrm{Sb}+\mathrm{Ma}))+\left(0,00000516(\mathrm{Tr}+\mathrm{Sb}+\mathrm{Ma})^{2}\right)\end{array}$ \\
\hline $\begin{array}{l}\text { Withers et al. } \\
\qquad(28)\end{array}$ & $\begin{array}{l}\text { Equation using } 7 \text { skinfolds, not fully published in the original } 1987 \text { paper by } \\
\text { Withers et al. (28), but can be found in Reilly et al. study (13) derived from } \\
\text { Withers et al. data. } \\
\qquad \mathrm{BD}=1,0988-(0,0004(\mathrm{Tr}+\mathrm{Sb}+\mathrm{Bc}+\mathrm{Sp}+\mathrm{Ab}+\mathrm{Th}+\mathrm{Ca}))\end{array}$ \\
\hline $\begin{array}{l}\text { Evans et al. } 1 \\
\qquad(18)\end{array}$ & $\begin{array}{c}\text { Equation using } 7 \text { skinfolds, gender and race. } \\
\% \mathrm{BF}=10,566+(0,12077(\mathrm{Sb}+\mathrm{Tr}+\mathrm{Ch}+\mathrm{Ma}+\mathrm{Si}+\mathrm{Ab}+\mathrm{Th}))- \\
(8,057 \mathrm{x} \text { gender })-(2,545 \mathrm{x} \text { race })\end{array}$ \\
\hline $\begin{array}{l}\text { Evans et al. } 2 \\
\qquad(18)\end{array}$ & $\begin{array}{c}\text { Equation using } 3 \text { skinfolds, gender and race. } \\
\% \mathrm{BF}=8,997+(0,24658(\mathrm{Ab}+\mathrm{Th}+\mathrm{Tr}))-(6,343 \times \text { gender })- \\
(1,998 \times \text { race })\end{array}$ \\
\hline $\begin{array}{l}\text { Oliver et al. } \\
\qquad(14)\end{array}$ & $\begin{array}{c}\text { Equation using } 7 \text { skinfolds (equation model number } 3) \\
\% \mathrm{BF}=3,53+(0,132(\mathrm{Ch}+\mathrm{Tr}+\mathrm{Sb}+\mathrm{Ma}+\mathrm{Si}+\mathrm{Ab}+\mathrm{Th}))\end{array}$ \\
\hline $\begin{array}{l}\text { Reilly et al. } \\
\qquad(13)\end{array}$ & $\begin{array}{c}\text { Equation using } 4 \text { skinfolds. } \\
\% \mathrm{BF}=5,174+(0,124 \times \mathrm{Th})+(0,147 \times \mathrm{Ab})+(0,196 \times \mathrm{Tr})+(0,13 \times \mathrm{Ca})\end{array}$ \\
\hline $\begin{array}{l}\text { Civar et al. } \\
\qquad(16)\end{array}$ & $\begin{array}{c}\text { Equation using } 3 \text { skinfolds and weight. } \\
\mathrm{BF} \%=(0,432 \times \mathrm{Tr})+(0,193 \times \mathrm{Ab})+(0,364 \times \mathrm{Bc})+(0,077 \times \mathrm{Wt})-0,891\end{array}$ \\
\hline $\begin{array}{l}\text { Stewart \& Han- } \\
\text { nan } \\
(17)\end{array}$ & $\begin{array}{l}\text { Equation using } 2 \text { skinfolds and weight. This equation estimates body fat in } \\
\text { grams, which are then converted into body fat percentage for BIA compari- } \\
\text { son. } \\
\qquad \mathrm{BFM}=(331,5 \times \mathrm{Ab})+(356,2 \times \mathrm{Th})+(111,9 \times \mathrm{Wt})-9108\end{array}$ \\
\hline
\end{tabular}

$\mathrm{Ht}$ - height; Wt - weight; BD - body density; BF\% - body fat percentage; BFM - body fat mass in grams; $\mathrm{Tr}$ - triceps skinfold; Ma - midaxilar skinfold; $\mathrm{Sb}$ - subscapular skinfold; $\mathrm{Ab}$ - abdominal skinfold; $\mathrm{Si}$ - suprailiac skinfold; Sp - supraspinale skinfold; Th - quadriceps skinfold; Ca - calf skinfold (medial calf); $\mathrm{Ch}$ - chest skinfold; $\mathrm{Bc}$ - biceps skinfold; gender - men $=1$; race - African American $=1$, Caucasian $=0$. 
Anthropometric measurement included the following ten skinfolds: subscapular, midaxillar, chest (pectoral), abdominal, biceps, triceps, suprailiac, supraspinale, quadriceps and medial calf. Locating and measuring skinfolds was conducted accordance with ISAK guidelines and recommendations (22). Additionally, Siri equation was applied to convert body density to body fat percentage for anthropometric equations that only estimated only body density (29). Determining the test-retest reliability of anthropometric measurement was performed using the method of technical measurement error (TEM) of a measurer, where a deviation of up to $7.5 \%$ for skinfolds and up to $1.5 \%$ for other anthropometric measures is considered acceptable. The calculation of the TEM was carried out according to the recommendations by Norton (23).

\section{RESULTS}

Ten anthropometric equations revealed a very large correlation with BIA method ( $\mathrm{rs}=0,70-0,89)$ while 6 anthropometric equations revealed a large correlation with BIA method ( $\mathrm{rs}=0,50-0,69)$. All sixteen anthropometric equations showed correlation statistical significance of $p<0,001$. Out of the ten anthropometric equations with a very large correlation coefficient, six equations slightly isolated and showed a correlation of 0,760 or larger (Yuhasz, rs $=0,769$; Faulkner, rs $=0,792$;

\section{Statistical analysis}

Statistical analysis was conducted using SPSS statistical program, package version 25 (30). Linearity for model validity, outliers and data normality distribution were checked using scatter plot graph, Q-Q plot, histogram, skewness and kurtosis and Kolmogorov-Smirnov test. Based on this, examining the correlation of anthropometric methods and BIA method was conducted using Spearman's rang correlation $\left(r_{s}\right)$, where values of $\left.r_{s}=0,0-0.09\right)$ were considered trivial, $r_{\mathrm{s}}=0,10-0,29$ small, $r_{\mathrm{s}}=0,30-0,49$ moderate, $r_{\mathrm{s}}=0,50-$ 0,69 large, 0,70-0,89 very large, 0,90 - 0,99 almost perfect and $r_{\mathrm{s}}=1$ perfect correlation (31). Descriptive data was described through means and standard deviations (mean $\pm \mathrm{SD}$ ). Statistical significance was set at 0,05 . Confidence interval was set at $95 \%$.

White et al., rs $=0,761$; Thorland et al. 1, rs $=0,760$; Evans et al. $1, \mathrm{rs}=0,761$; Oliver et al., $r \mathrm{rs}=0,761$ ). Out of these six equations, along with their highest correlation coefficients, the narrowest bias-corrected and accelerated confidence interval was revealed in equations of Yuhasz with interval length of 0,191 (BCa CI 95\% $(0,649-0,840))$, Faulkner with interval length of 0,137 (BCa CI 95\% $(0,712-0,849)$ ) and White et al. with interval length of 0,174 (BCa CI 95\% $(0,665$ - 0,837)), isolating these three equations furthermore from the rest.

Table 3. Correlation of different anthropometric methods and BIA method in assessing body fat percentage of professional male athletes.

\begin{tabular}{|c|c|c|c|c|c|}
\hline \multirow{2}{*}{ Method } & & \multirow{2}{*}{$\mathbf{N}$} & \multirow{2}{*}{$\mathbf{r}_{\mathrm{s}}$} & \multicolumn{2}{|c|}{ BCa CI 95\% } \\
\hline & & & & lower & - upper \\
\hline Yuhasz (25) & vs BIA & 85 & $0,769 * * *$ & 0,649 & - 0,840 \\
\hline Faulkner (26) & vs BIA & 85 & $0,792 * * *$ & 0,712 & - 0,849 \\
\hline Forsyth \& Sinning 1 & vs BIA & 85 & $0,743 * * *$ & 0,619 & - 0,823 \\
\hline Forsyth \& Sinning 2 (11) & vs BIA & 85 & $0,738 * * *$ & 0,627 & - 0,019 \\
\hline Forsyth \& Sinning 3 (11) & vs BIA & 85 & $0,676 * * *$ & 0,536 & $-0,775$ \\
\hline Forsyth \& Sinning 4 (11) & vs BIA & 85 & $0,685 * * *$ & 0,545 & $-0,786$ \\
\hline White et al. (12) & vs BIA & 85 & $0,761 * * *$ & 0,665 & - 0,837 \\
\hline Thorland et al. 1 (19) & vs BIA & 85 & $0,760 * * *$ & 0,650 & - 0,848 \\
\hline Thorland et al. 2 (19) & vs BIA & 85 & $0,736 * * *$ & 0,613 & $-0,830$ \\
\hline Whiters et al. (13) & vs $\mathrm{BIA}$ & 85 & $0,674 * * *$ & 0,502 & - 0,796 \\
\hline Evans et al. 1 (18) & vs BIA & 85 & $0,761 * * *$ & 0,642 & - 0,845 \\
\hline
\end{tabular}




\begin{tabular}{llllll}
\hline Evans et al. $2(18)$ & vs BIA & 85 & $0,674 * * *$ & $0,518-0,791$ \\
\hline Oliver et al. (14) & vs BIA & 85 & $0,761 * * *$ & $0,614-0,843$ \\
\hline Reilly et al. (13) & vs BIA & 85 & $0,681 * * *$ & $0,535-0,793$ \\
\hline Sivar et al. (16) & vs BIA & 85 & $0,740 * * *$ & $0,625-0,819$ \\
\hline
\end{tabular}

BIA - bioelectrical impedance; $r_{s}$-Spearman's correlation coefficient; $p$ - statistical significance;

$* * *$ - $\mathrm{p}<0,001$; BCa CI 95\% - bias-corrected and accelerated confidence interval, set at 95\% confidence.

\section{DISCUSSION}

The aim of this study was to identify if any of the existing anthropometric methods developed for male athlete population (general or specific) are applicable to general male athlete population as replacement for BIA method. A trend can be noticed of publishing studies in journals across the world that are developing and suggesting new population-specific anthropometric methods and equations for determination body fat percentage. It is also noticeable that the most numerous of these population-specific methods are developed for specific or general athlete populations $(13,14,16,17,32)$ and for nation-specific populations (specific to anthropology or characteristics of a certain nation) $(32,33,34,35,36,37)$. Publishing and suggesting a large number of anthropometric methods and equations for athlete population, which amounts up to tens of equations developed for popular sports, can be confusing and exhausting for coaches and sport experts when they are making a decision in selecting and applying anthropometric method for their athletes. Also, being exposed to numerous anthropometric methods increases the chances for selecting inadequate anthropometric method for their athletes which can lead to significant mismanagement in regulation of body fat percentage. Examples of inadequate selection of anthropometric methods in practice can be noticed when coaches and sport experts apply popular anthropometric methods developed for general or general male non-athlete population such as Jackson and Pollock (38), Durnin \& Womersley (39), Sloan (40) or Lohman (41) for their male athlete population.

The specificity of anthropometric methods should cover parameters or factors of gender, race, age, method and protocol used for skinfold measuring, condition level or competition level, nation (anthropology) etc. All these factors should be taken into consideration during the selection of specific or general athlete anthropometric methods and equations. This means that even if coaches or sport experts decide to select an anthropometric method developed on the sample of athletes from the same sport, chances are that even that method won't be precise enough for their athletes unless all aforementioned factors of specificity match with the athletes which comprised the sample in the development of that anthropometric method. Considering everything said, it can be roughly concluded that the only precise anthropometric method for athletes would have to include coaches or sport experts conducting their own anthropometric measurement and applying regression analysis, thereby developing their own anthropometric equations using only their athletes as the sample. These kind of complications and uncertainties can influence coaches and sport experts to avoid using anthropometry and to prefer the use of BIA method for assessing body fat percentage. As aforementioned, anthropometry also has advantages in field practice. For example, anthropometric equipment takes up a lot less space than BIA instruments, it weights less and doesn't possess any electrical components therefore creating almost no risk from damage during transport. These can be significant advantages of anthropometry compared to BIA when athletes are obligated to travel to preparation camps or competitions, especially if we are considering transporting a higher quality and bigger size (therefore more expensive as well) BIA instrument.

Precision of BIA analysis can be affected by physiological oscillations in human body and potential physiological oscillations during airplane travel or longer land travel, and also it requires athletes to deal with a long and unpopular preparation protocol (48 hours) and requires coaches trust that athlete fully complied with the preparation protocol before BIA analysis, while anthropometry is based on anatomical measurements which require a much simpler athlete testing preparation. In conjunction with the previous, authors of this study considered that it would be useful to examine and provide athletes, coaches and other sport experts with an option of applying an existing anthropometric method to general male athlete population that reveals the closest correlation coefficient to BIA method and therefore can be used as BIA replacement in field practice, either by circumstantial need, personal preference, or simply to eliminate uncertainty and potential selection of inadequate anthropometric methods for specific athletes, which are usually lacking specificity factors.

Anthropometric methods and equations today are numbered by the hundreds. For this study, we selected more common and known anthropometric methods developed for athletes that are used in practice up to a few decades back. Results of all sixteen anthropometric equations revealed a strong correlation with BIA method, which is somewhat interesting considering that some of the included 
anthropometric methods and equations were developed using samples of athletes coming from different sports, using general samples of athletes, using different reference methods (DXA, MRI, CT, ADP etc.), applying different models for assessing body composition (two-component, three-component, four-component, etc.), probably with large technical error of skinfold measurement caused by different anthropometry measurers (inter-tester TEM) and protocols, and in the time span of more than 40 years (changes in average athletes body composition and constitution over decades), so it would be more logical that some anthropometric methods reveal much more different correlation coefficients than others in comparison with BIA method.

Results of this study showed that six anthropometric equations with Spearman's coefficient of $r_{s}=0,760$ or stronger, somewhat distanced themselves in correlation with BIA method compared to other methods, even though this distance was minimal. Out of these six equations, Yuhasz, Faulkner and White et al. equations separate themselves furthermore at the top with correlation coefficients of $r_{s}=0,769$, $\mathrm{r}_{\mathrm{s}}=0,792 \mathrm{i}_{\mathrm{s}}=0,761$, and with bias-corrected and accelerated confidence interval length of 0,191 (BCa CI 95\% (0,649 $0,840)), 0,137$ (BCa CI 95\% (0,712 - 0,849)) and 0,174 (BCa CI $95 \%(0,665-0,837))$. Even though it used to be seen mostly in studies examining statistical difference, lately, a trend of calculating and adding confidence intervals as important correlation indicators can been noticed in correlation studies as well. The reason for this is that correlation coefficients attained in correlation studies refer to our observed sample from a specific population, while for example a confidence interval of $95 \%$ tells us that in $95 \%$ of cases a true correlation coefficient for our targeted population (in this case professional male athletes) should fall within attained confidence interval range of an individual anthropometric method and BIA method. A shorter length (narrower range) of confidence interval leads to the assumption that the correlation coefficient for our observed sample $\left(\mathrm{r}_{\mathrm{s}}\right)$ must be close to the true correlation coefficient for our specific population, or at least closer than those correlation coefficients with wider confidence interval lengths. Besides revealing the highest correlation coefficients, Yuhasz, Faulkner and White et al. anthropometric equations also revealed the shortest confidence intervals ranges, and alongside Thorland et al. 1 and Civar et al. equations, these three were the only equations revealing confidence intervals shorter than 0,2 and therefore indicated correlation coefficients closer to the true correlation coefficient than other anthropometric methods when correlated with BIA method.

Faulkner's anthropometric method or equation revealed the highest correlation coefficient, reaching almost $r_{s}$ of 0,80 when compared with BIA method. Faulkner's equation was originally considered a method developed for a population of swimmers (26), however motivated by the lack of evidence of it's development, in 2007 Pires-Neto and Graner managed to reveal and point out that this method is actually a modified Yuhasz method (27). Furthermore, by answering the question proposed by Pires-Neto and Graner in 2006 about this methods origin, Faulkner reveals that this equation was modified by Yuhasz himself by combining data of two anthropometric equations which were previously published in his dissertation in 1962. (42), but he couldn't remember how exactly Yuhasz performed this modification (27). Pires-Neto and Graner then suggested that Faulkner's equation should be addressed as Yuhasz's unpublished equation, because evidence revealed that Faulkner did not develop this equation by using a sample of swimmers. By further analyzing Faulkner's equation and comparing it with other studies, among other finding Pires-Neto and Graner state da Faulkner's equation is applicable to young trained male population (27). This part of Pires-Neto and Graner's conclusion matches the results obtained in this study. A young trained male population can be compared with a sample of relatively young athletes $(23,7 \pm 4,3$ years of age) from this study, while a sample of young athletes from different sports in this study (wrestling, football, boxing, basketball) can be compared with the sample used for Yuhasz's method (university martial arts athletes and swimmers, basketball players selected for Olympics and others), or in other words, can be compared with the sample from Yuhasz's population from which the Faulkner's equation was developed.

One of the main limitations of this study was the lack of reference method of second level of validity for estimating body fat, by which besides determining the correlation with BIA method we could also determine if one of the selected anthropometric methods for athletes in this study correlates more accurately than BIA method, for our professional male athlete population. Without a reference method, results of this study can only showcase if one of the existing anthropometric methods is applicable as a replacement for BIA method on general male athlete population. By adding a second level of validity reference method, we would also be able develop a new anthropometric equation based on the athlete sample like the one in this study.

\section{CONCLUSION}

This study examined weather any of existing and relatively used anthropometric methods reveal sufficiently similar results to BIA method within male population of professional athletes. This can provide coaches and sports experts an easier selection and enable them an option to replace BIA method with one of the already existing sports anthropometric methods, eliminating at the same time the risk of selecting an inadequate method. Faulkner's anthropometric method (unpublished Yuhasz's equation) showed the largest correlation and the narrowest bias-corrected and accelerated confidence interval with BIA method thus suggesting that this correlation coefficient probably deviates least from the professional male athletes population's true correlation coefficient. This further indicates that it would be very useful and interesting to repeat this kind of study or similar one with the addition of one of the second level of validity reference methods such as magnetic resonance, computed tomography or dual-energy X-ray absorptiometry. 


\section{REFERENCES}

1. Ostojic SM. Changes in body fat content of top-level soccer players. J Sports Sci Med. 2002;1(2):54-5.

2. Reilly T. Science and Soccer. In: Reilly T, editor. London: E. \& F.N. Spon; 1996. p. 25-49.

3. Ostojic SM, Zivanic S. Effects of training on anthropometric and physiological characteristics of elite Serbian soccer players. Acta Biol Med Exp. $2001 ;(27): 48$.

4. Reilly T, Collins K. Science and the Gaelic sports: Gaelic football and hurling. Eur $\mathrm{J}$ Sport Sci. 2008;8(5):231-40.

5. Torres Navarro V, Campos Granell J, Aranda Malavés R. Influencia de la masa grasa para el VO2max y Umbrales Ventilatorios en jóvenes deportistas de especialidades deportivas de resistencia. Sport Sci J Sch Sport Phys Educ Psychomot. 2016;3(1):530.

6. Ramos NJ, Zubeldía GD. Masa Muscular y Masa Grasa, y su relación con la Potencia Aeróbica y Anaeróbica en Futbolistas de 18 a 20 años de Edad (Parte II). PubliCE. 2003; 173.

7. Kelly RA, Collins $K$. The seasonal variations in anthropometric and performance characteristics of elite intercounty gaelic football players. J Strength Cond Res. 2018;32(12):3466-73.

8. Stojanović D, Branković N. Association Between Body Composition and Cardiorespiratory Fitness of Adolescents. Facta Univ Ser Phys Educ Sport. 2018;16(2):297.

9. Mooses M, Hackney AC. Anthropometrics and Body Composition in East African Runners: Potential Impact on Performance. Int $\mathrm{J}$ Sports Physiol Perform. 12(4):422-30.

10. Heyward VH, Wagner D. Applied Body Composition Assessment. 2nd ed. Champaign (IL): Human Kinetics; 2004. $280 \mathrm{p}$.

11. Forsyth HL, Sinning WE. The anthropometric estimation of body density and lean body weight of male athletes. Med Sci Sports. 1973;5(3):174-80.

12. White J, Mayhew JL, Piper FC. Prediction of body composition in college football players. J Sports Med Phys Fitness. 1980;20(3):317-24.

13. Reilly T, George K, Marfell-Jones M, Scott M, Sutton L, Wallace JA. How well do skinfold equations predict percent body fat in elite soccer players? Int J Sports Med. 2009;30(8):607-13.

14. Oliver JM, Lambert BS, Martin SE, Green JS, Crouse SF. Predicting football players' dual-energy x-ray absorptiometry body composition using standard anthropometric measures. J Athl Train. 2012;47(3):25763.

15. Bell W. Football Players. 1995;29(1):46-51.

16. Civar S, Aktop A, Tercan E, Ozdol Y, Ozer K. Validity of leg-to-leg bioelectrical impedance measurement in highly active women. J Strength Cond Res. 2006; 20(2):359-65.

17. Stewart AD, James Hannan W. Prediction of fat and fatfree mass in male athletes using dual $\mathrm{x}$-ray absorptiometry as the reference method. J Sports Sci. 2000;18(4):263-74.

18. Evans EM, Rowe DA, Misic MM, Prior BM, Arngrímsson SÁ. Skinfold prediction equation for athletes developed using a four-component model. Med Sci Sports Exerc. 2005;37(11):2006-11.

19. Thorland W, Johnson G, Tharp G, Housh T, Cisar C. Estimation of body density in adolescent athletes. Hum Biol. 1984;56:439-45.

20. Ostojic SM. Estimation of body fat in athletes: Skinfolds vs bioelectrical impedance. J Sports Med Phys Fitness. 2006;46(3):442-6.

21. Utter AC, Scott JR, Oppliger RA, Visich PS, Goss FL, Marks BL, et al. A Comparison of Leg-to-Leg Bioelectrical Impedance and Skinfolds in Assessing Body Fat in Collegiate Wrestlers. J Strength Cond Res. 2001;15(2):157-60.

22. Stewart A, Marfell-Jones M, Olds T, de Ridder H. Preliminary considerations. In: Stewart A, Marfell-Jones M, Olds T, de Ridder H, editors. International Standards for Anthropometric Assessment. 3rd ed. Lower Hutt, New Zealand: International Society for the Advancement of Kinanthropometry; 2011. p. 12.

23. Norton K. Standards for anthropometry assessment. In: Norton, K., Eston, R. (Eds.), Kinanthropometry and Exercise Physiology. London: Routledge, Taylor \& Francis Group; 2018. 131-2 p.

24. Gibson, Ann L, Wagner, Dale R, Heyward VH. Advanced Fitness Assessment and Exercise Prescription. 8th ed. Champaign, Ilinois: Human Kinetics; 2018. 262 p.

25. Yuhasz MS. Physical Fitness Manual. 1'. London, Ontario: University of Western Canada; 1974.

26. Faulkner JA. Physiology of swimming and diving. In: Falls H Exercise physiology. Baltimore: Academic Press; 1968. p. 415-46.

27. Pires-Neto SC, Glaner MF. Ponto de vista "Equação de Faulkner" para predizer a gordura corporal: $\mathrm{O}$ fim de um mito The "Faulkner equation" for predicting body fat: The end of a myth. Rev Bras Cineantropometria e Desempenho Hum. 2007;9(1415-8426):207-13.

28. Withers R, Craig N, Bourdon P, Norton K. The relative body fat and anthropometric predicition of body density of male athletes. Eur J Appl Physiol Occup Physiol. 1987;56(2):191-200.

29. Siri WE. Body composition from fluid spaces and density: Analysis of methods. In: Brožek, J.Hanschels A, editor. Techniques for Measuring Body Composition. Washington, D.C.: National Academy of Science; 1961. p. 223.

30. IBM SPSS Statistics for Windows. Armonk, NY: IBM Corp; 2017.

31. Hopkins WG, Marshall SW, Batterham AM, Hanin J. Progressive statistics for studies in sports medicine and exercise science. Med Sci Sports Exerc. 2009; 41(1): 3-13.

32. Riyahi-Alam S, Mansournia MA, Kabirizadeh Y, Mansournia N, Steyerberg E, Kordi R. Development and Validation of a Skinfold Model for Estimation of Body 
Density for a Safe Weight Reduction in Young Iranian Wrestlers. Sports Health. 2017;9(6):564-9.

33. Eston RG, Fu F, Fung L. Validity of conventional anthropometric techniques for predicting body composition in healthy Chinese adults. Br J Sports Med. 1995;29(1):52-6.

34. Demura S, Yamaji S, Goshi F, Kobayashi H, Sato S, Nagasawa $Y$. The validity and reliability of relative body fat estimates and the construction of new prediction equations for young Japanese adult males. J Sports Sci. 2002;20(2):153-64.

35. Davidson LE, Wang J, Thornton JC, Kaleem Z, SilvaPalacios F, Pierson RN, et al. Predicting fat percent by skinfolds in racial groups: Durnin and womersley revisited. Med Sci Sports Exerc. 2011;43(3):542-9.

36. Hastuti J, Kagawa M, Byrne NM, Hills AP. Development and validation of anthropometric prediction equations for estimation of body fat in indonesian men. Asia Pac J Clin Nutr. 2013;22(4): $522-9$.
37. Liu X, Sun Q, Sun L, Zong G, Lu L, Liu G, et al. The development and validation of new equations for estimating body fat percentage among Chinese men and women. Br J Nutr. 2015;113(9):1365-72.

38. Jackson AS, Pollock ML. Generalized equations for predicting body density of men. 1978; British Jo(40):497-504.

39. Durnin J, Womersley J. Body fat assessed from total body density and its estimation from skinfold thickness: measurements on 481 men and women aged from 16 to 72 years. Br J Nutr. 1974;32(1):77-97.

40. Sloan AW. Estimation of body fat in young men. J Appl Physiol. 1967;23(3):311-5.

41. Lohman TG. Skinfolds and body density and their relation to body fatness: a review. Hum Biol. 1981;53(2):181-225.

42. Yuhasz MS. The effects of sports training on body fat in man with predictions of optimal body weight. [Doctoral Dissertation - Phylosophy in Physical Education in the Graduate College of the University of Illinois]. Urbana (IL): University of Illinois; 1962. 